\title{
Ethnologies
}

\section{The Second Greatest Disappointment: Honeymooning and Tourism at Niagara Falls. By Karen Dubinsky. (Toronto: Between the Lines, 1999. 290 p., illus., \$29.95. ISBN 1-896357-23-7)}

\section{Pamela Coristine}

Volume 24, numéro 2, 2002

Musées

Museums

URI : https://id.erudit.org/iderudit/006654ar

DOI : https://doi.org/10.7202/006654ar

Aller au sommaire du numéro

Éditeur(s)

Association Canadienne d'Ethnologie et de Folklore

ISSN

1481-5974 (imprimé)

1708-0401 (numérique)

Découvrir la revue

Citer ce compte rendu

Coristine, P. (2002). Compte rendu de [The Second Greatest Disappointment:

Honeymooning and Tourism at Niagara Falls. By Karen Dubinsky.

(Toronto: Between the Lines, 1999. 290 p., illus., \$29.95. ISBN 1-896357-23-7)].

Ethnologies, 24(2), 259-261. https://doi.org/10.7202/006654ar

Ce document est protégé par la loi sur le droit d'auteur. L'utilisation des services d'Érudit (y compris la reproduction) est assujettie à sa politique d'utilisation que vous pouvez consulter en ligne.

https://apropos.erudit.org/fr/usagers/politique-dutilisation/ 
underlies this final chapter, illustrated in Dawson's words, "histories... are central to the understanding of national identity and contemporary Canadian debates" (185). While it would perhaps have been more satisfying to abandon a historical summary at the end of the text, Dawson's book does leave the reader with food for thought, namely about symbol and community and representation of nation and nationhood.

Kristin Harris

Memorial University of Newfoundland

The Second Greatest Disappointment: Honeymooning and Tourism at Niagara Falls. By Karen Dubinsky. (Toronto: Between the Lines, 1999. 290 p., illus., \$29.95. ISBN 1-896357-23-7)

In the Introduction to The Second Greatest Disappointment, Karen Dubinsky confides to the reader that her inspiration for the book is both her "own adult curiosity about the culture in which my parents came of age" (2) and her discovery of Niagara Falls, Ontario as "the greatest theme park of heterosexuality I had ever witnessed" (3). The author states that her work is basically a history of tourism at Niagara Falls, but it is more than that. By framing tourism's development through the honeymoon, Dubinsky sheds light upon the forces that helped shape and develop Niagara Falls into a North American cultural icon.

The scope of the book is ambitious and the author's approach justifiably interdisciplinary. Using source materials that span two centuries, Dubinsky argues that the association of the honeymoon with Niagara Falls evolved over time along with people's attitudes towards sexuality, particularly heterosexuality.

While its reputation as the "honeymoon capital of the world" crystallized after the Second World War, the process began with the wedding tours of the $19^{\text {th }}$ century when the town of Niagara Falls was a popular summer resort among the monied classes.

From this early period of development comes the story of a business rivalry that became so bitter a Royal Commissioner, Edmund Burke Wood, was appointed to investigate visitors' complaints. Researchers who are interested in the conflicts that arise over space when its meaning is imposed from without will find this account worthy of note. The 
commissioner's criticisms of the town's visitor services and his recommendation that the provincial government take control of an area that reached to the foot of the waterfall "initiated a conflict between local authorities and provincial 'reformers' that continued well into the twentieth century" (88). The subsequent creation of Queen Victoria Park ensured a scenic and public space from which to view the feminine allure of Niagara - and of the construction spurred on by early $20^{\text {th }}$ century industrial development. Although objections to this development, particularly of a power plant, were won over "by proclaiming electrical development as the manifest destiny of white men" (102) the tourism industry's promotion of the now illuminated falls as a "must-see" for visitors also helped dispel the discord.

The author's confessed interest in the postwar period comes through in the later chapters of the book. Beginning with the dramatic impact of the automobile on tourist patterns in the 1920s and 30s, and the exploitation of hospitality industry workers, it is in these chapters that the case for the association of the honeymoon with the growth of tourism is most strongly presented. And as the honeymoon became an increasingly popular ritual, Dubinsky argues it also played a pivotal role in the public demonstration of a heterosexual identity, particularly in the 1950s when journalists on the "Niagara beat" spent their time "watching besotted honeymooners do silly things in public" (240).

Although Dubinsky does quote from visitors and town developers, the voices of those who lived in the area appear infrequently. If this local perspective had been more deeply explored, this volume would be of more interest to ethnologists. Of what appears, the most intriguing is the reminiscences of those who worked in the hotel industry during the 1930s and 40s. Dubinsky's use of pop-culture from various eras, however, does go a long way to putting a human face on the area's development. The images generously distributed throughout the text also enhance its appeal.

One of the difficulties with Dubinsky's work is that it is difficult to place within the field of expectations of any one discipline. Each chapter takes a theme and follows it through from one century or decade to another. Yet, each chapter also sequentially foregrounds historical eras as the argument progresses, and thereby the book attempts to follow a historical framework. It is a structure that occasionally leads to confusion. Generally, the evidence she employs is historical material, 
such as journals, newspaper items, and travel guides. Art historians will find her use of illustrations, advertising texts, and landscapes insightful. There are also sources here that will be of interest to the literary scholar. For example, Dubinsky cites Charles Dickens, Oscar Wilde, H.G. Wells, and Jane Urquhart, to name a few. The author's references to the formation of legends, the material culture associated with the region's tourism, the occupational folklore of hackmen and cab drivers, as well as the traditions surrounding honeymoons and marriage provide a great deal to arouse the interest of folklorists.

Cultural anthropologists will find the insights into the lives of the area's disenfranchised and the references made to queer culture especially notable. But while the presence of the "other" at Niagara Falls "importuning hackmen, exotic Indians, and fearsome guides" (80) is a fascinating thread it is one that Dubinsky ultimately leaves dangling. As a counterpoint to the development of Niagara's heterosexual text, the author does not take her analysis of this presence far enough.

The book's interdisciplinary approach makes The Second Greatest Disappointment, an ambitious project, more palatable to those generally interested in pop culture, and to a lesser degree, in queer studies. The work mainly suggests how the tourism industry at Niagara Falls has commodified the ideals and dreams which attend romance. Like many cultural practices, marriage - or why, when, and how two individuals legally commit themselves to one another - is not only learned, but is ever evolving. The book also serves as a timely warning to those who would promote the development of tourism without regard to its economic impact on resident populations and regional economies.

Pamela Coristine Memorial University of Newfoundland

Folk and Fairy Tales. By Martin Hallett and Barbara Karasek, eds. (Peterborough, Broadview Press, 2002. xxv + 454 p., preface, introduction, index, selected bibliography, list of sources, colour and black/white photographs, \$24.95 CDN, \$18.95 US, ISBN 1-55111-495-X)

This book is an anthology of folk tales, mostly Märchen. The stories are grouped into related sets, each with its own introduction. Some sets, such as the section on "Cinderella," consist of different versions of the same story. Other sets are thematically linked. The section on Damsels 